\title{
ADRB3 Gene
}

National Cancer Institute

\section{Source}

National Cancer Institute. ADRB3 Gene. NCI Thesaurus. Code C126971.

This gene plays a role in the modulation of the physiological effects of catecholamines. 